\title{
Medical education - historic perspective and future challenges
}

\author{
Luiz Fernando Ferraz da Silva ${ }^{1}$, Edmund Chada Baracat ${ }^{2}$
}

Silva LFF, Baracat EC. Medical education - historic perspective and future challenges/ Educação médica - perspectiva histórica e desafios futuros. Rev Med (São Paulo). 2016 July-Aug.;95(Special Issue 1):28-36.

\begin{abstract}
The history of medical education is binded to the history of medicine itself once teach, learn and practice happens together. Since ancient times the role of the mentor / tutor is the key to practical learning. Over time, and particularly in the last 300 years, the medical knowledge expansion and new technologies incorporation brought drastic changes in medicine and, therefore, in medical education but yet, the presence of one or many reference doctors in medical learning is still an important part of thousands of undergraduate students every year. In this period new concepts, new teaching techniques and use of multiple technologies including distance learning and simulation were included in several medical curricula. In this article we seek to briefly present the key events of the evolution of medical education including some particularities of medical education in Brazil and at USP School of Medicine, as well as point out the challenges for the ongoing century.
\end{abstract}

KEYWORDS:Education, medical/history.
RESUMO: A história da educação médica é riquíssima e imiscui-se com a própria história da medicina já que o exercício da arte médica está intimamente ligado ao seu ensino e aprendizado. Desde os tempos antigos a figura do mentor / tutor é a chave para o aprendizado prático. Ao longo do tempo e particularmente nos últimos 300 anos, a ampliação dos conhecimentos e a incorporação de novas tecnologias fez com que a medicina e, por conseguinte, a educação médica, fossem drasticamente transformadas, ainda assim, o aprendizado prático e o papel de um ou muitos médicos de referência ainda fazem parte da realidade de milhares de novos médicos que se formam a cada ano. Neste período foram introduzidos e aprimorados conceitos, novas técnicas de ensino e uso de múltiplas tecnologias incluindo ensino à distância e simulação. Neste artigo buscamos, de forma breve, apresentar os eventos chave desta evolução, particularidades da realidade brasileira e da Faculdade de Medicina da USP bem como os desafios para o século em andamento.

DESCRITORES: Educação médica/história.

1. Universidade de São Paulo, Faculty of Medicine, Pathology Department. E-mail: burns@usp.br.

2. Universidade de São Paulo, Faculty of Medicine, Gynecology and Obstetrics Department. e-mail: ecbaracat@usp.br.

Mailing address: Av. Dr. Arnaldo, 455 - 1st floor - Room 1155. São Paulo, SP, Brasil. ZIP Code: 01246-903. 


\section{INTRODUCTION}

"The process of medical education consists of equipping the student with contemporary technical and scientific knowledge and to mold them to be the right kind of person in order to apply this knowledge, as a professional, to individuals and communities. These are the two fundamental purposes of medical education: one is academic and the other is social. One teaches medicine facts and evidences, the other form the doctor"'.

$\mathrm{T}$ hese consepts were published by Robinson ${ }^{1}$ in 1958 but, if we look at medical education from a historical perspective, we can notice thatthey permeate the art of medical teaching and learning throughout the years.

Despite all the historical and cultural bumps and changes observed during the evolution of medical knowledge and medical education, its easy to recognize a common feature that remains also a pillar of the medical education: the role of a mentor / a master whose example must be followed!. A single mentor or a pool of them, to a greater or lesser degree, at the earliest or latest moments or even throughout the learning process (depending on the time period or the learning model) this "reference" has always been a unique character in the transmission of medical knowldge including its different dimensions such as technical aspects, social responsibility and humanitarian behavior.

Another relevant aspect to be considered is that the main goal of medical education has changed little over time, or has not changed at all, this goal being the development of professionals able (in the broader sense) to identify and treat health problems in other human beings. Obviously, increments and adjustments have broadened these concepts, including, for example, the health promotion and prevention of diseases and not just their treatment. In spite of the renewed and modernized concpets the central axis remains relatively unchanged when compared to the early days of medical art.

The methodologies employed to achieve these goals, however, differ considerably according to the historical period and context. Thus, the so-called "evolution of medical education" meddles with the very history of medicine and is strongly connected to its remarkable facts. The detailed relations between the history of medicine and the history of medical education could take an an entire issue of this Revista de Medicina (Journal of Medicine), so in this article we will seek to highlight only the key points of this relation pointing out relevant historical periods / facts and the related developments in medical education.

\section{HISTORICAL ASPECTS}

\section{Ancient Times}

The first systematized historical records on diseases and healing strategies date from the heyday of the Egyptian and Hindu civilizations. Also, from this period on, the need to transmit this knowledge through the generations was made clearer. The first registered mention to medical education in the literature is attributed to Charaka, a Hindu physician who in $500 \mathrm{BC}$ referred to the distinctive idea of a "master" from whom one could learn the medical art and practice. According to him the master should "profess and practice the art with recognized and approved skills, be an expert, righteous, irreproachable and know how to use his hands and senses, be committed to learning, without extreme attitudes of tardiness or passion and be patient and tender towards his or her followers"'.

This characterizes the first stage of medical education, focused on master-apprentice relationship. It blossomed in the Hindu, Arabic, Greek and Roman cultures, and is responsible for the dissemination of knowledge and its replication. At this time those who were interested in learn the medical skills sought the best masters, accompanying them in their daily activities, in order to learn the current medicine, in a direct and personal way.

Although this strategy had been disseminated in several civilizations at that time, it was in Greece that it blossomed the most (together with the advance of the Greek domination over a significant portion of the inhabited territory) and developed with the addition and standardization of the use of the first written texts by Alcmaeon (510AC-?) and Hippocrates (460 AC-377 AC) which would become a medical reference until around the Renaissance era. Still, in the Greek structure of medical 
teaching, the experience has always been considered more important than the theoretical learning, and the practical training was obtained directly from the mentors, whereas their writte books were only supporting instruments containing descriptions of the diseases and details about how they were recognized and understood at that time. These writings, however, represented the first major step of the so-called "scientific" medicine, since they were based on empiricism and refuted superstition and magical practices $^{3}$.

In the second century after Christ this strategy remained active and was reinforced by Galen ${ }^{4}$ who used anatomy textbooks to teach his apprentices, once the human dissections were forbidden at that time. Interestingly, the ban on human dissections in this period, already under the domain of the Roman Empire, was the driving force for the expansion of the detailed documentation of the few (and often illegal) procedures performed, thus enabling greater uniformity in the teaching provided to the apprentices.

\section{Middle Ages}

In the high middle ages, while Europe sank in its scientific obscurantism, the Greek and Roman teaching strategy remained alive in Persia with Ibn Sina (Avicenna - 980-1037), who at that time produced, among others, the "Book of Healing" and the "Canon of Medicine" which, along with the writings of Hippocrates and Galen, represented the basis of the texts adopted by the universities throughout this historical period ${ }^{5}$.

The first "medical school" as institution arouse in the Ninth century in Salerno. Far less eloquent than the Greek and Roman period in terms of publications and discoveries (especially considering the restrictions of the medieval period), Salerno became the most important medical learning center of that time. The major contribution of Salerno to our topic is the systematization. The Salerno Medical School brought out for the first time the separation between theory and practice in medical education as those contents were taught in different classes. It also featured the loss of the exclusive masterapprentice relationship. In this context, the "master" started being represented by a group of "masters" ${ }^{6}$. Once back to their original countries, graduates from
Salerno created new medical schools and disseminated this "way of teaching" in France (Montpellier and then Paris), Spain and England. In these schools, Hippocratic and Galenic texts were still used, but new texts were also included, many of them were aligned with theology and incorporated the structure and culture of that time, though without greater scientific innovation. It is worth highlighting the leading role of Roger Bacon (1214 to 1294) in this period, a great disseminator of the concept of University throughout Europe. Bacon advocated the importance of acquiring knowledge from original research and not only from the existing authorities. He was a man ahead of his time, and this position generated considerable criticism, but he could already foresee the developments of medicine in the future.

\section{Modern and Contemporary Age}

The Renaissance transformed the history of medicine as it did to humanity as a whole. Great Italian medical schools such as Padua, Bologna and Pisa began adopting the scientific spirit and expanding their search for knowledge. At this time, the role of Andreas Vesalius (1514-1564) as a scholar and educator stands out. Padua became the medical education center in Europe and its graduates have been responsible for major discoveries of modern medicine such as circulation (described by William Harvey on his way back to his homeland $)^{20}$.

With the initial technological advance, the development of the scientific method and the increase in laboratory research, medical knowledge continued to advance throughout the period in areas such as pathology, physiology and microbiology, where the German leadership was clear considering the outstanding discoveries performed by Virchow (1821-1902), Muller (1801-1858) and Robert Koch (1843-1910) in the respective areas ${ }^{21}$.

Alongside this development appeared the challenge of incorporating this knowledge as the basis for medical education. To address this challenge in nineteenth-century Europe, the medical schools links to Universities became a rule. In the European Universities major curricular changes were made at this time including: 1) inclusion of basic knowledge through theoretical classes and 
laboratory practices; 2) inclusion of professors who were committed to teaching and research; 3) integral dedication to basic subjects in the first years of training; 4) students practical activities with patients developed under supervision of physicians of renowned clinical and didactic skills in selected hospitals ${ }^{7}$.

The challenge of this merger was well expressed by Locke and Sydenham ${ }^{24}$ when they mentioned that the full medical training would include: "initially his preliminary science studies and throughout the medical curriculum, the training and encouragement to obtain the talent and habit of continuously, seriously and patiently seeking information for diagnosis and treatment" (p.21). He also stressed that "The student must also have full opportunity to practice daily. In Medicine, the art of healing cannot be smaller or larger than the Science of Disease" (p.22). Addressing the same theme, Willian Osler8 (1849-1919), when talking about the clinical cycle of medical education, emphasized that "the student begins with the patient, continues with the patient and ends his studies with the patient, using books and classes as tools, as means to an end. Teach him how to observe, give him many facts to be observed and the lessons will come from these facts" (p.110) ${ }^{8}$.

Since then, the search for integrating basic and clinical knowledge for a better balance between theory and practice has been arduously pursued through different strategies all around the world.

\section{Medical Education in the Twentieth Century}

Until the middle of the nineteenth century in the United States most of the medical schools was founded without any link to Universities resulting in a large number of schools with doubtful quality, to say the least. To deal with the problem of its 155 medical schools, the Medical Education Council was created in the United States. This council was responsible for evaluating the schools, determining which of them would remain open and which would be closed and the criteria that would be used as standards for opening and maintaining medical schools around the country. At that time, two major event lead to a real change of course in medical education.

The first one was the creation of the Johns Hopkins
University School of Medicine in Baltimore in 1893 (with the participation of Osler as Internal Medicine chief), a model of the ideal pre-medical scientific training teached by full-time researchers followed by clinical training in university hospitals teached by professors of the highest clinical skills 9 .

The second was the publication of the Flexner Report10, a result of the aforementioned evaluation visits by the Medical Education Council. The report considered the Johns Hopkins University an outstanding example and set high standards for new medical schools. The main observed consequences were the reduction in the number of medical schools and the increased qualitative demand in the United States. The same standards were required by Rockefeller Foundation from the University of São Paulo (USP) School of Medicine (FMUSP) in order to sponsor its headquarters building, which was completed in 1931. The implementation and maintenance of such standards granted FMUSP the recognition of its diplomas by the American Medical Association - The Flexner Report became a reference for the development of curricula and medical schools not only in the United States but also in Europe, Latin America and Asia over the following years $^{11}$.

Throughout the twentieth century, particularly in its second half, medical knowledge expanded exponentially both in basic and clinical areas. Besides that, the historical context of the ongoing century, featuring its wars and worldwide conflicts, generated a complete reinterpretation of human rights, labor relations and ethics, translated into medicine in concepts such as patient safety, codes of ethics for students, etc which have become critical in the development and implementation of medical curricula around the world.

The time reserved for the basic sciences became narrow in the face of the known level of detail. The time for clinical aspects of diseases also became limited by the expansion of knowledge and the arising of different specialties. In such a way it became clear that it would impossible to cover all the available knowledge. Given this new reality, some new developments were observed:

1. The first steps towards a competence-based curriculum: since knowledge had become broad and diverse, it was now paramount to define which of them 
were essential, and also what was expected of future professionals in terms of acquired skills and attitudes. This concept, which emerged most clearly during the second half of the twentieth century, has evolved to the point where it became a key element in the curricula of the best medical schools in the world ${ }^{12}$;

2. Extended Training: in the medical field the most widespread and historically established example is medical residency, which also began at Johns Hopkins?. Advocating practical learning in real supervised activity, it was the best solution found to ensure that the newly graduated doctors acquired experience and detailed knowledge in specific areas;

3. Broadening of the students' autonomy and the separation between a core curriculum and a number of elective disciplines and optional internships: the first initiative in this direction was the Yale Plan in 1917 from the Yale University, who advocated (1) a list of common core subjects, (2) periodic examinations for students, and (3) some additional time for the pursuit of student's own interests ${ }^{2}$. This strategy, which was strongly criticized in the 1920s, proved to be successful, being replicated and refined over the years in several other universities.

This new reality transformed the scenario of medical education in the twentieth century and the more the research in basic areas deepened, the more these researchers and professors dove into its developments and, in a way, they lost contact with an applied, straightforward view of this issues in medical practice. The immediate effect of this process was the excessive detailing of basic contents (seeking to cover more content) and the lack of encouragement to the students (who could not see the direct application of those contents in practice).

Then, the first strategies to aiming to contextualize and integrate basic and clinical areas begin to appear. Problem Based Learning (PBL) experiments seeking to contextualize the learning of basic contents from problems proved to be effective ${ }^{13}$. Initially planned to be used as an exclusive tool for the entire curricular structure, the PBL became, years later, an excellent complementary tool that, combined with other strategies, allow for the contextualization, integration and active learning process. In the first years of the twenty-first century, Team Based Learning sought to add teamwork and interpersonal relationships to the learning context, essential competencies for doctors ${ }^{14,23}$. Both techniques are student-centered, but with the active participation of a mentor or tutor, which reinforces the importance of the master-apprentice relationship, but from a different hierarchical perspective of knowledge acquirement.

While contextualization gained strength and there was a tendency to precociously put the student in contact with the patient, we faced the obvious patient safety limits. To address this challenge, the simulation labs were developed, with increasingly realistic scenarios and mannequins, capable of reproducing numerous clinical and surgical conditions and complications, providing an excellent environment for testing and learning prior to the direct exposure of the student to the patient ${ }^{15}$.

From the second decade of the twenty-first century on, the medical schools begin to receive Generation $\mathrm{Z}$ (Millennial) students, who are born already under the aegis of a world which is globalized, dynamic and fully connected by the Internet. This admittedly immediatist generation demands more and more integration and contextualization, which is obtained in various medical schools through the use of many of the aforementioned strategies. This very generation now demands adaptations not only from a structural point of view, but also from related to the applied teaching tools. Online learning platforms begin to be developed then; also, threedimensional features, augmented reality, connectivity, interactivity and dynamism in the search and exchange of knowledge. It has been a real challenge for teachers from a previous generation, to understand these demands and to learn and apply such tools in their courses

\section{Characteristics of the Brazilian reality}

The first medical schools in Brazil were founded upon the arrival of D. João VI to the colony in 1808 (Rio de Janeiro and Bahia). The third school appeared in the Republic already, in Rio Grande do Sul (1895). From 1911 on other schools started to appear in the Southeastern, Southern and Northeastern Brazil, all of them partially adopting the newly published Flexnerian strategy. Until 1963, there were 36 medical schools in Brazil and from there on we can observe three great 
waves of medical schools creation: the first wave, from 1970 to 1985 when we reached 76 schools (an average of 2 new schools per year), the second wave, from 1995 to 2010 , with an increase of about 6.5 schools per year, reaching 178 schools and finally the period from 2011 to 2015, with glaring 22 new schools per year, reaching the current amount of 266 medical schools ${ }^{16}$.

Ignoring whether there is or not the need for a greater number of doctors, the creation of such a large number of schools in such a short period of time leads us back to what happened in the United States in the nineteenth century. This increase certainly does not find reasonable support in terms of teaching hospitals and professors in the basic and clinical areas who are fit and adequately trained for teaching. Add to it the inefficiency and ineffectiveness of the quality control system of the medical schools and we cannot be surprised by the poorquality level of the doctors trained in Brazil.

Despite this reality and despite the difficulties found in appreciating the medical education, many medical schools in the country are seeking to adapt to the previously described, innovating in their curricula, seeking to use integration tools in an accurate and systematic way, and implementing technological advances. This tireless pursue of excellence, combined with the the efforts of gifted students and professors, offer good prospects for its future graduates and consequently to society.

\section{The medical education at Universidade de São Paulo School of Medicine}

Receiving its first class in 1913, the so called São Paulo School of Medicine and Surgery adopted the same strategy used by the best European and North American schools at that time (reinforced by the publication of the Flexner report). To meet the needs of the basic subjects, internationally renowned visiting professors, such as Alfonso Bovero and Alessandro Donatti (from Italy) and Lambert Meyer and Emilio Brumpt (from France), among others, were invited and lately incorporated as permanent faculty. With the Rockefeller Foundation's support and, in turn, the obligation to institute all the key points in the Flexner Report, the School earned its headquarters building in 1931. In 1934 the then São Paulo
Faculty of Medicine and Surgery became crucial to the creation of USP, becoming a part of it and maintaining the same teaching principles adopted until then. Less than 40 years after it was founded, in 1951 FMUSP received the " A Standard" recognition granted by the American Medical Association, meaning that the doctors who graduated from the FMUSP had, according to the Association, the same level as those who graduated from the best schools in the United States ${ }^{17}$. FMUSP continued to adopt the Flexner report precepts focused on dedicated basic areas and full time professors, numerus clausus and reference teaching hospital. Regarding this last topic is worth remembering that much of the clinical teaching in FMUSP was developed and supervised by professors and doctors at Santa Casa de Misericórdia and other specific hospitals. These teaching activities have been transferred to Hospital das Clínicas since its debut year in 1944.

During 1968 a "University Reform" was established in the country. One of the key points of this reform was the centralization of the basic sciences (previously hosted and taught in each school) in specific Institutes including Biomedical Sciences, Chemistry, Physics, among others. From the administrative point of view and from the perspective of reducing operational costs these changes could even make sense, but from an educational point of view this movement created a huge gap, removing the basic sciences from the FMUSP's structure. At first, many of the basic sciences Professors at FMUSP continued to develop their activities in the new Institutes, but as time passed by, this identity has been lost, generating even more difficulties in the integration and contextualization processes already discussed in this text.

In the same year of 1968 the Congregation of the FMUSP approved the creation of the Experimental Medicine Course (Experimental) that had as premises breaking with the traditional structure of isolated disciplines, creating theme blocks and also the focus on the formation of the so-called "general" medicine, trying to avoid early specialization ${ }^{18}$. The Experimental was developed in parallel to the traditional curriculum, making the FMUSP feature twice as many students, which clearly overloaded the physical structure and human resources at that time. The Experimental had its first class in 1969 and its last class beginning in 1975. 
From 1976 on the Unified Curriculum began. It was now offered to the 180 students entering FMUSP, and characterized by a mixture of the two curricula, with the prevalence of the structure and vision of the traditional curriculum, but maintaining, in some areas, the concepts of the Experimental (such as the set of subjects on infectious diseases). This unified curriculum underwent several adjustments and important structuring, and it counted on the support of the Medical Education Development Center (Centro de Desenvolvimento da Educação Médica - CEDEM) founded in 1991. In 1998, after a major curriculum reform, the FMUSP Nuclear Curriculum were implemented. It was characterized by the allocation of $30 \%$ of the time in the schedule for optional activities, among which was Scientific Initiation. This new vision was challenging due to the proportional reduction in teaching hours aiming to open spaces for the elective courses, and therefore adaptations of content and teaching strategies were needed. Changes that were planned in the initial structure but were implemented later included dedicated primary health care and humanities subjects, simulation and evaluation through Objective Structured Clinical Examination (OSCE).

From 2011 to 2014 new curricular discussions were encouraged all over FMUSP and several steps were taken towards a new curriculum reform, implemented for the 2015 freshmen, with a competence-based curriculum ${ }^{22}$. This proposal not only reduces the classroom activities workload, but it also rescues part of the organ/systemblock structure (used in the Experimental and in several universities abroad) and includes, in an objective way, communication and humanities competences permeating the various areas and disciplines. It also advocates a 4th year with practical activities aimed at preparing the students for medical internship. The expansion of the optional activities to the internship and the acknowledgment of complementary activities in this proposal, such as leagues, courses and sports activities, is an important step to incorporate part of the hidden curriculum, valuing it and increasing the student's autonomy, enthusiasm and responsibility towards his/her own training. In this new proposal, it is also worth highlighting the inclusion of independent biannual formative assessment strategies that have the dual function of (1) evaluating the course and (2) monitoring the student. The major challenges of this new curriculum include the integration of professors in the preparation and implementation of the theme blocks and the incorporation of technology at various levels, from the availability of educational content to the development of extra-class activities.

\section{Prospects and Future Challenges}

In view of this dynamic and living reality that the twenty-first century has brought to humanity and consequently to the medical education, the challenges that arise are also opportunities to pursue the constant development of the process of learning the medical art.

Currently, some medical schools such as Harvard have the audacity to offer different medical curricula at the same time so that the students can choose which one they want to attend according to their final performance and career goals.

Many schools have adopted the content integration strategy using theme blocks (as in the case of the new FMUSP curriculum). Although studies have not shown any difference between this strategy and the traditional strategy of disciplines (mostly adopted until the end of the twentieth century) in the achievement and professional performance of the students yet, some studies have shown a positive impact on the students' perception of integration ${ }^{19}$.

As the three-dimensional models and simulation strategies advance, the task of seeking balance between the use of these tools and the interaction with the real patient becomes challenging. Even though it is easier to be replicated, the simulation should serve as a preparation for practical training with the patient, aiming to ensure the patient's safety - and not to replace him, after all, developing the student's self-confidence to deal with the real patient, inserted in society and multifaceted, is also the medical school's responsibility as shown in the opening quote of this article.

Lastly, we walked increasingly, as in other segments, towards the personalization of teaching and learning. Recognizing that different students learn in different ways is a reality from which we cannot escape. All we can do is using our creativity and the technological 
resources available to ensure that our students can learn in the most effective and enjoyable way for them, which entails one last big challenge.

In view of this plurality of knowledge and methods, how can the student be evaluated, not only regarding his acquired knowledge, but also skills and attitudes, ensuring that we deliver to the society a doctor trained in every sense of the word. Much has been studied in this regard and different techniques are being applied by various institutions, but we are still far from a common understanding and this is certainly one of the greatest challenges for the medical education in our time.

\section{CONCLUSIONS}

Medical education evolves in the shape of a spiral. While it revisits important concepts from the past, it

\section{REFERENCES}

1. Robinson GC. Adventures in medical education. Toronto: The Commonwealth Fund by Harvard University Press. Cambridge, Mass.: S. J. Reginald Saunders; 1958.

2. Fulton OBE. History of medical education. BMJ. 1953;2(4834):457-461. Available from: http://www.jstor. org/stable/20312376

3. Jouanna J. Hippocrates as Galen's teacher. In: Horstmanshoff $\mathrm{M}$, editor. Hippocrates in medical education. Selected papers presented at the XIIth International Hippocrates Colloquium, Universiteit Leiden, 24-26 August 2005. Leiden: Brill; 2005.

4. Pormann PE. Medical education in late antiquity from Alexandria to Montpellier. Stud Anc Med. 2010;35:419-41.

5. Saffari M, Pakpour AH. Avicenna's Canon of medicine: a look at health, public health, and environmental sanitation. Arch Iran Med. 2012;15(12):785-9. doi: 0121512/AIM.0015.

6. Stelmaschuk A. The School at Salerno: origin of the European Medical University. In: Whitelaw WA, editor. Proceedings of the10th Annual History of Medicine Days. Calgary; 2001. p.65-71. Available from: http://www.ucalgary.ca/uofc/ Others/HOM/Dayspapers2001.pdf\#page $=77$

7. Os caminhos da educação médica [editorial]. Rev Assoc Med Bras. 2004;50(3):229-30. http://dx.doi.org/10.1590/ S0104-42302004000300001.

8. Osler W. The evolution of modern medicine. New Heaven; 1921. p.110.

9. Harvey AM, Brieger GH, Abrams SL, Fishbein JM, assigns new values and dimensions to these concepts in view of the historical context of the present moment. This can be observed in different aspects such as the masterapprentice relationship, in the balance between theory and practice and in the use of different learning tools

The dynamism of the society and the generations has been demanding, on one side, from the educators (from previous generations) an extreme capacity to adapt to more immediate and technological realities and on the other side, from the students, the awareness that immediacy and self-sufficiency have clear limits that cannot be overcome. It is this dynamic and living context that the upcoming challenges will be faced, so that the medical education can continue to fulfill its academic fundamental purposes (to teach the facts and evidences of medicine) and social purposes (to create the doctor) in the current context.

McKusick VA. A model of its kind. A centennial history of medicine at Johns Hopkins. Baltimore: Johns Hopkins University Press; 1989. v.1.

10. Flexner A. Medical education in the United States and Canada. Bulletin Number Four (The Flexner Report). New York: Carnegie Foundation for the Advancement of Teaching; 1910. Available from: http://archive.carnegiefoundation. org/pdfs/elibrary/Carnegie_Flexner_Report.pdf.

11. Duffy TP. The Flexner report -100 years later. Yale J Biol Med. 2011;84(3):269-76. Available from: http://www.ncbi. nlm.nih.gov/pmc/articles/PMC3178858/.

12. Ford K. Competence based education - history, opportunities and challenges. Available from: https://www.umuc.edu/ innovatelearning/upload/cbe-lit-review-ford.pdf.

13. Davis MH. AMEE medical education guide $\mathrm{n}^{\circ}$ 15: problem-based learning: a practical guide. Med Teach. 1999;21(2):130-40. doi: 10.1080/01421599979743.

14. Issa N, Mayer RE, Schuller M, Wang E, Shapiro MB, DaRosa DA. Teaching for understanding medical classrooms using multimedia design principles. Med Educ. 2013;47(4):38896. doi: $10.1111 /$ medu. 12127 .

15. Murray DJ. Progress in simulation education: developing an anesthesia curriculum. Curr Opin Anaesthesiol. 2014;27(6):610-5. doi: 10.1097/ACO.0000000000000125.

16. Conselho Federal de Medicina (CFM). Radiografia das escolas médicas do Brasil. Brasília; 2015. Disponível em: $\quad$ http://webpainel.cfm.org.br/QvAJAXZfc/opendoc. htm?document=Radiografia $\% 20 \mathrm{do} \% 20$ Ensino $\% 20$ 
m\%C3\%A9dico\%2FRadiografia\%20do\%20Ensino\%20 $\mathrm{m} \% \mathrm{C} 3 \%$ A9dico.qvw\&host $=\mathrm{QVS} \% 40 \mathrm{scfm} 73$ \&anonymous $=$ true.

17. Lacaz CS. Faculdade de medicina: reminiscências, tradição, memória de minha escola. São Paulo: Ed. do autor; 1985.

18. Tavano PT. Tramas da tessitura curricular: o curso experimental de medicina da Faculdade de Medicina da USP [Tese]. São Paulo: Universidade de São Paulo, Faculdade de Educação; 2015.

19. Moore GT. The influence of the New Pathway curriculum on Harvard medical students. Acad Med. 1994;69(2):983-9.

20. Kiple KF. The history of disease. In: Porter R, editor. Cambridge illustrated history of medicine. Cambridge: Cambridge University Press; 2001.

21. Gilder SSB. The evolution of medical education. Can
Med Assoc J. 1958;78:530-1. Available from: http:// www.ncbi.nlm.nih.gov/pmc/articles/PMC1830043/pdf/ canmedaj00778-0067.pdf.

22. Smith SR, Dollase RH, Boss JA. Assessing students' performances in a competency in a based curriculum. Acad Med. 2003;78(1):97-107. Available from: http:// journals.lww.com/academicmedicine/Fulltext/2003/01000/ Assessing_Students_Performances_in_a.19.aspx.

23. Thompson BM, Schneider /vf, Haidet P, Levine RE, McMahon KK, Perkowski LC, Richards Bf. Team-based learning at ten medical schools: two years later. Med Educ. 2007;41(3):250-7. doi: 10.1111/j.1365-2929.2006.02684.x. doi: 10.1111/j.1365-2929.2006.02684.x.

24. Newman G. Some notes on medical education in England. London: His Majesty's Stationery Office; 1918. p.21. Available from: https://archive.org/details/ somenotesonmedic00newmuoft. 